\author{
بررسى تغييرات يوشش اراضى استان جهارمحال و بختيارى با استفاده از \\ متريكهاى سيماى سرزمين (10 (199Y-Y. \\ راحله دانشمند يارسا اوץ*" روح اله ميرزايى و و ندا بىهمتا'

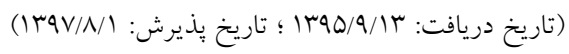

جكيده

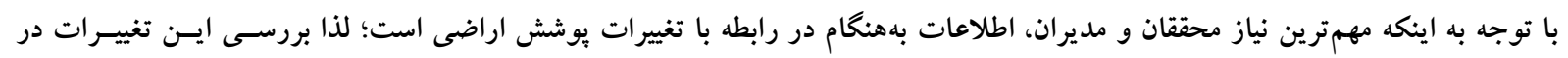

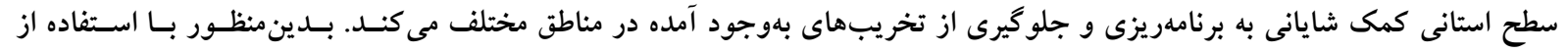

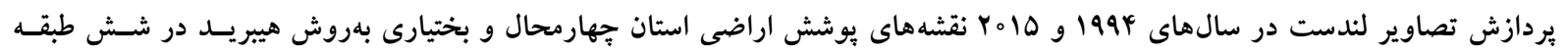

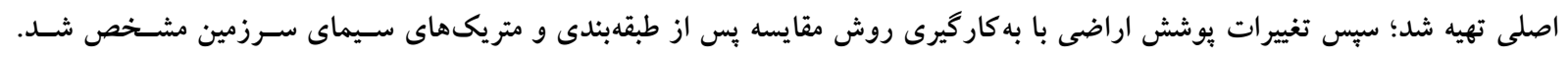

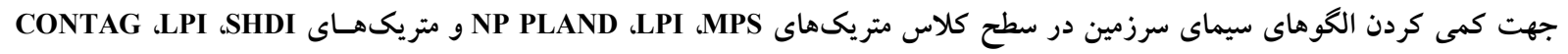

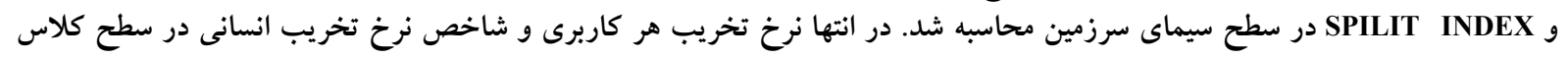

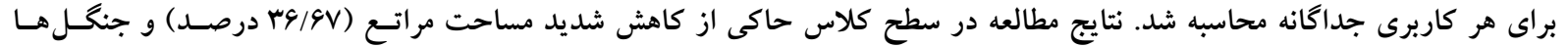

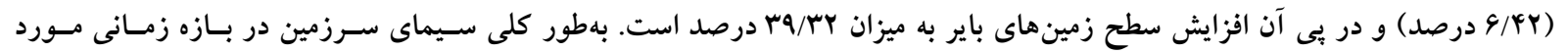

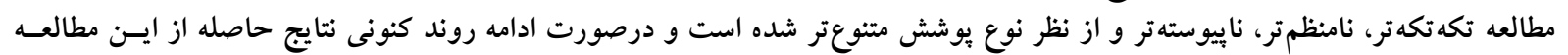

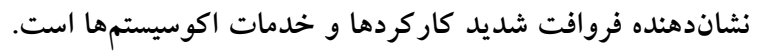

وازههاى كليدى: جهارمحال و بختيارى، سيماى سرزمين، سنجش از دور، متريك، هيبريد

ا. I. دانشكده منابع طبيعى، دانشكاه صنعتى اصفهان

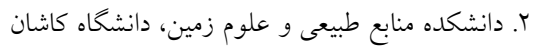

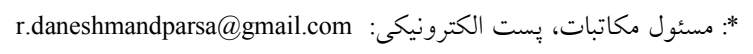


بلهنوان نقشههـاى بِايـهـ و مبنـا جهـت بررسى و كمسى كـردن

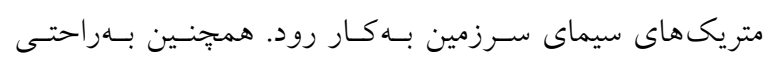

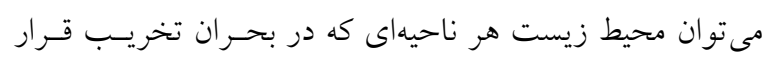

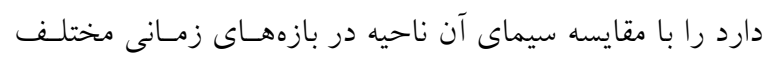

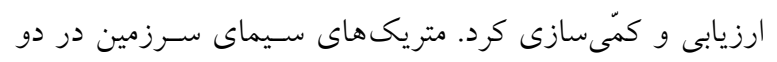

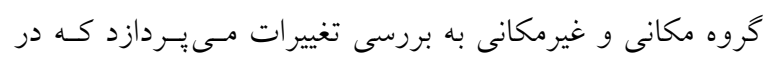

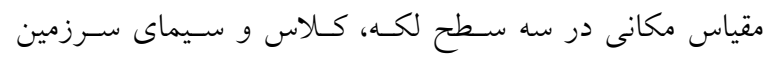

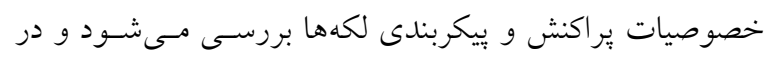
مقياس هاى غيرمكانى به بررسى تركيب سيماى سـرزمين مانتسـ

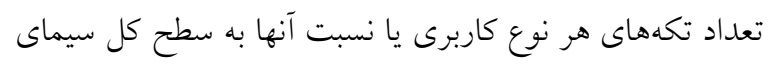

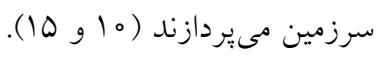

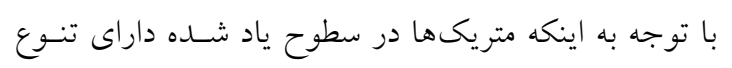

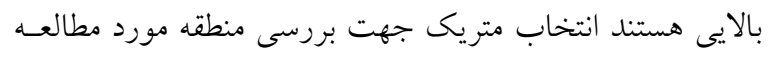

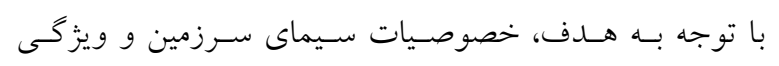

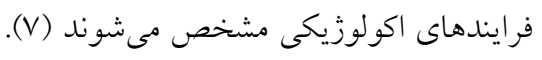

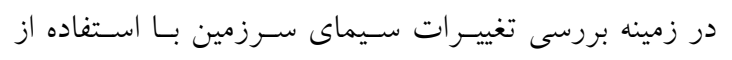

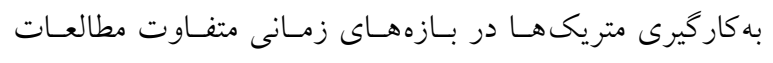

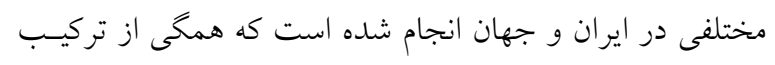

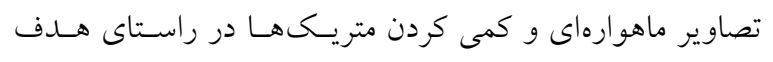

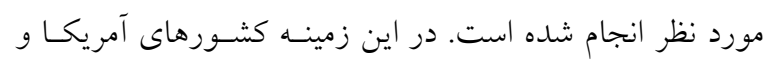

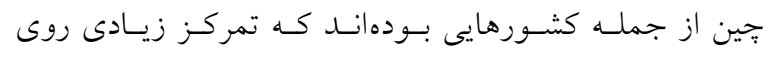

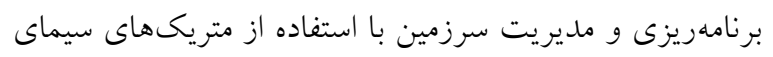

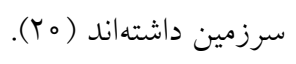
تركيب يردازش تصاوير ماهوارهاى و تهيه نقشههاى بوشش

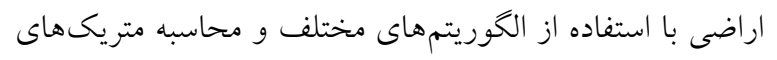

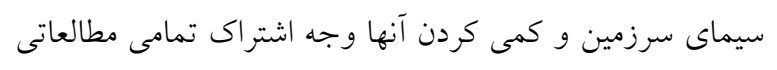
است كه در اين زمينه انجام شده اسـت. اسـتفاده از متريـكهــا

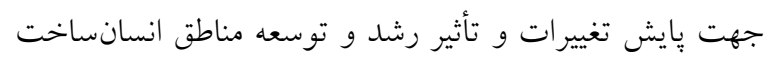

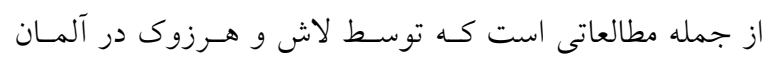

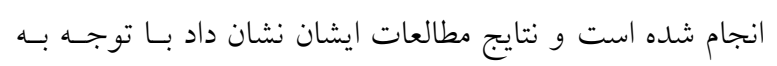

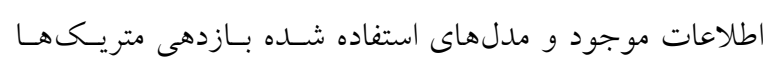

$$
\text { متفاوت خواهد بود مودو (11). }
$$

\section{مقدمه} رشد جمعيت و توسعه فعاليتهاى انسانى در سـالهـاى اخيـر باعث تغييرات زيادى در يوشش هاى طبيعى از جملـه مراتع و جنخل ها شده است. عو املى كه باعـث ايسن تغييـر شـدهانـد را بهطور كلى مى توان به دو دسته تقسيم كـرد؛ عوامـل طبيعى از

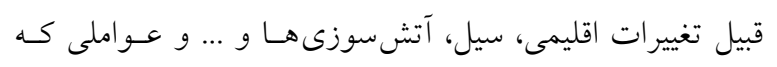
بشر در آن دخالت دارد مانند توسعه شهرى، جراى بيش از حلد، احداث جاده، قطع درختان، افزايش حجم ساختوساز و توسعه

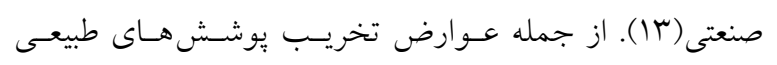

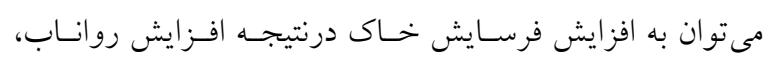
افزايش كردوخاى و كاهش كيفيت هوا و در معرض خطر فر قرار

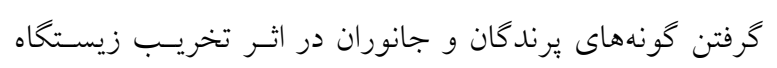

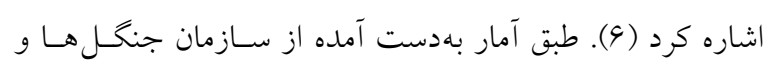

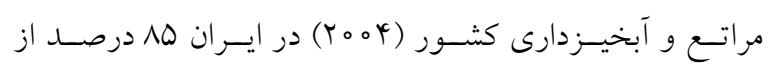
يوششهاى طبيعى از جمله جنخل ها و مراتع در معسرض خطـر

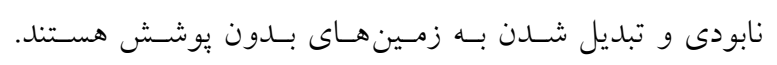

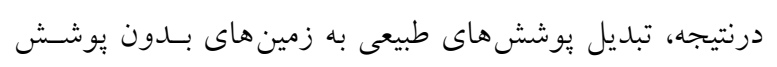

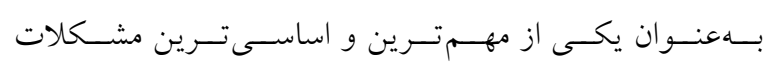

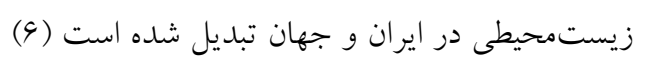
مفهوم بومشناسى سيماى سرزمين با هدف مطالعه تغييـرات ناهمخنى مكانى سيماى سرزمين ارتباطات و تبـادلات اجـز ادر سيماى سرزمين، آثار ناهمخنى مكانى روى فرايندهاى زيستى و غيرزيستى و مديريت ناهمخنى هاى مكانى براى نخستين بـار در

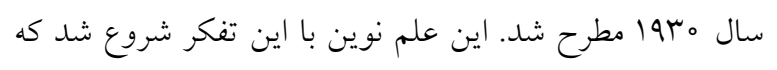

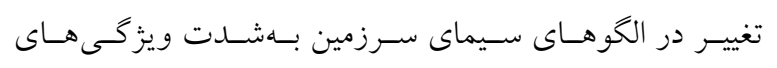
بومشناسى را تحت تأثير قرار مىدهـد (هو و 1)). در ايسن علـم ساختار، عملكرد و تغييرات داراى ارتباط متقابل با يكديخر بوده و شالوده مطالعات بومشناسى سيماى سرزمين را تشكيل مى دهد

امروزه استفاده از علم سنجش از دور و استفاده از تصـاوير

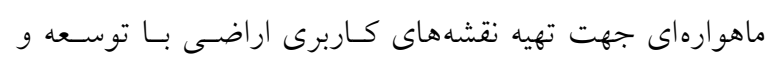

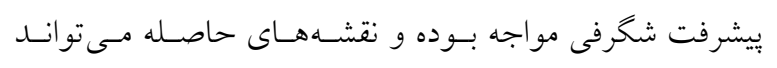


نظر به اينكه تغيير كاربرى اراضى و از بين رفتن سطح جنگل ها و مناطق طبيعى مشـكلى جهـانشـمول اسـت و در ايـران نيـز

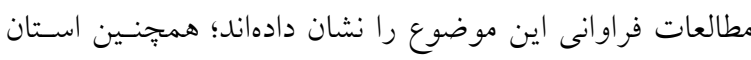

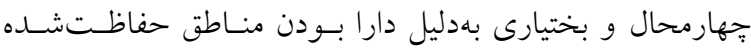

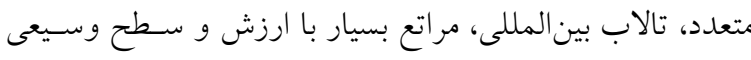

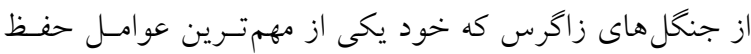
تنوع زيستى است در سالهاى اخير دهار تخريب شديدى بوده است و همين عامل باعث شده تا منطقه حجم بوشش سبز خود

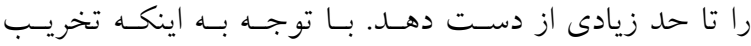

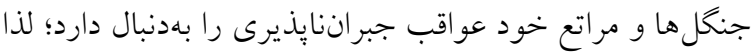
ارزيابى وضعيت موجود و بررسى تغييرات بهوجود آمده در هر مر بردي

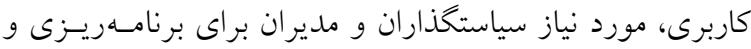

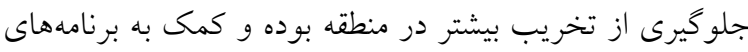

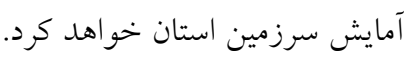

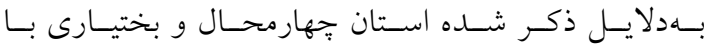

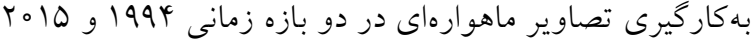
مورد مطالعه قرار كرفت. در اين مطالعه بِ از تهيه نقشههاى

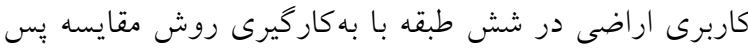

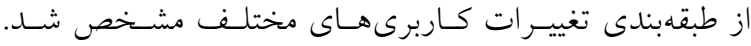

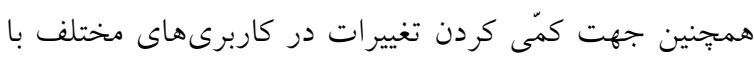

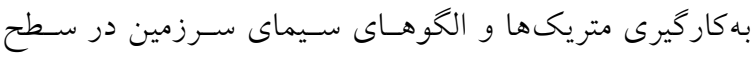
كلاس و سيماى سرزمين طى بازه زمانى بيست ساله تغييـرات حاصله مشخص شد.

\section{مواد و روشها - (- ماد

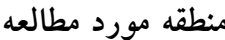

محدوده مورد مطالعه اسـتان جهارمحـال و بختيـارى بـوده كـهـ براساس آخرين تقسيمات سياسى كشور شـامل شهرسـتانهـاى شهركرد، سامان، بن، بروجن، لردگان، اردل، فارسان، كوهرنغ و كيار است (شكل 1). استان جهارمحال و بختيارى بـا مسـاحت لترنت

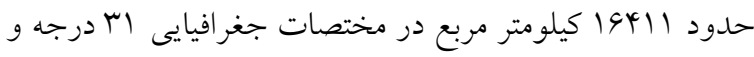

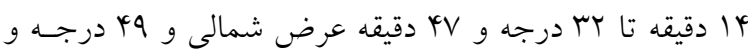

مطالعاتى كه توسط كن كو و شيو جــنج در تـايوان جهـت

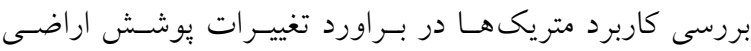

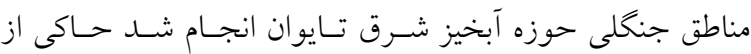
كارايى و بازدهى بالاى متريكها در كرد تغييرات جنغل بهسوى كوجى شدن، ايزوله شدن و تخريب شدن لكسهــا، و افـزايش بىنظمى در كاربرى جنگل بوده است (1). نتيجه مطالعات تلفيق تكنيك سنجش از دور بههمراه استفاده

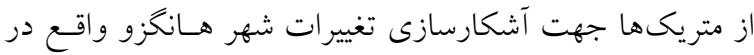

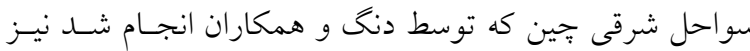

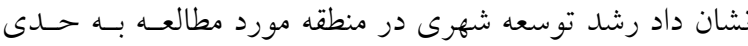
بوده است كه اكثر كاربرىها تبديل به كاربرى انسانساخت شده (9) (9) (9) (9)

شرستا و همكاران در منطقه فنيكس با بهكارگيرى دادههـاى

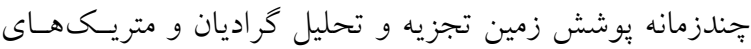
سيماى سرزمين در تخريب الكوهاى سيماى سـرزمين را ناشسى از رشد سريع شهرنشينى دانستند. در اين بـزوهش يـنج فـاكتور اصلى يويايى جمعيت، فنـاورى حمـلونقـل، عوامـل بنيـادى و تويــوَرافى و تـأمين آب بـراى درك فراينــدهاى شهرنشـينى و تخريب الكوها شناسايى شدند (19).

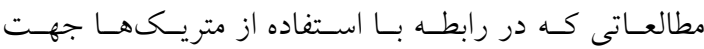
آشكارسازى تغييرات صورت كرفته كه تعـدادى از آنهـا شـامل

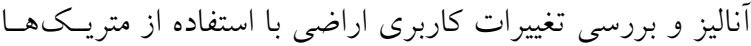
توسط دزكام و همكاران (Y)، ميرزايى و همكاران (Q)،عسكريان و همكاران (r) بى همتـاى طوسى و همكـاران (1) در منـاطق

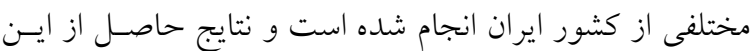
مطالعات نشان مىدهد تغييرات خصوصيات مكسانى در كـاركرد اكولوزيكى منطقه اثر داشته و اكثــــــالعـات حساكى از افـزايش درصد مناطق انسانساخت بوده كه خود تأثير منفى روى ديخــ كاربرىها از جمله كاهش سطح جنكل ها بوده است. بهطور كلى سلى

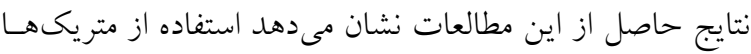

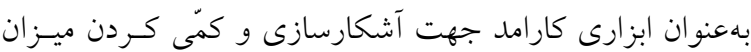

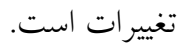




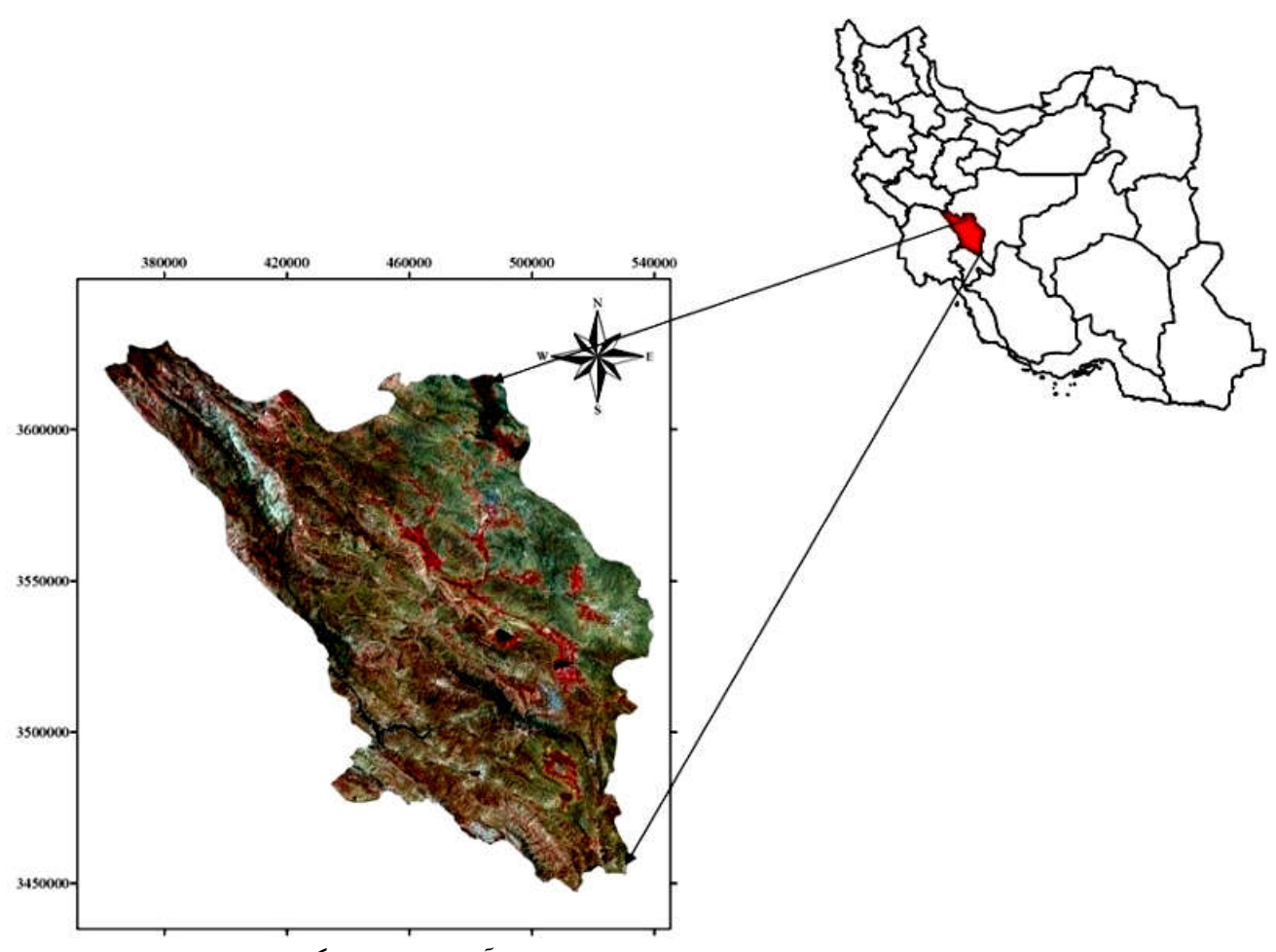

شكل ا. منطقه مورد مطالعه استان جهارمحال و بختيارى و موقعيت آن در ايران (رنكى در نسخه الكترونيكى)

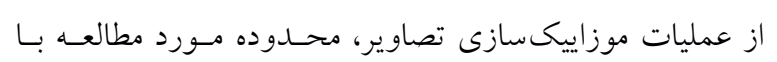

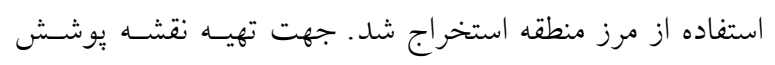
زمين، تصاوير تهيه شده با استفاده از روش هيبريد و استفاده از

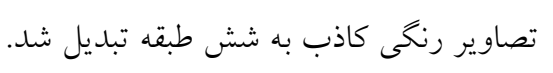

با توجه بـه شـناخت از منطقسه و بـا بررسسى تصـاوير

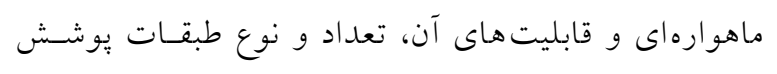
اراضى مورد نظر تعيين شد و منطقه مورد مطالعه به شـش

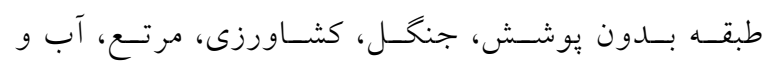

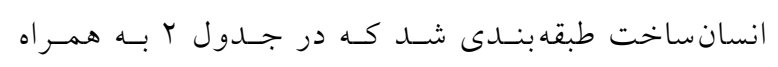
مشخصات آنها نشان داده شده است. جهت تفكيـى يوشـش جنخـل، مرتسع و كشـاورزى از شاخص تفاوت نرمال شـده كيـاهى NDVI بـا اسـتفاده از

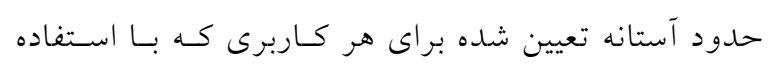

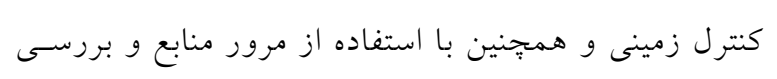

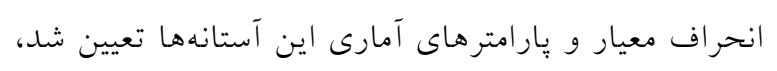
تفكيك شدند. q دقيقه تا اه درجه و بr دقيقه طول شرقى قرار گرفته است. استان جهارمحال و بختيارى داراى يُستى و بلنـدى زيـادى

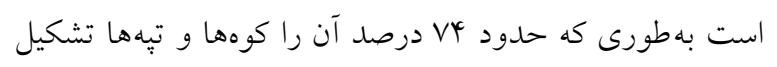

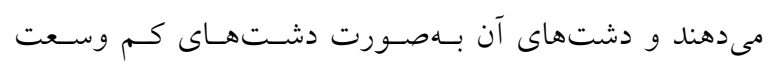
ميانكوهى است. بلندترين قسمت منطقه قلل زردكوه با ارتفـاع

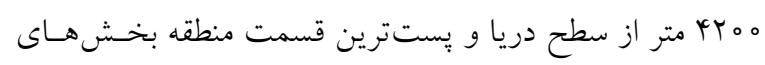
جنوبى با ارتفاع حدود هo متر از سطح دريا قرار دارد. روش كار با توجه به اينكه استان جهارمحسال و بختيـارى در جهـار فـريم تصاوير سنجندههـاى TM و ETM مـاهوارهاى لندسـت قـرار كرفته بود؛ ابتدا با به كارگيرى نرمافـزار 5.1 ENVI تصـحيحات راديومتريـك بـا اسـتفاده از اطلاعــات موجــود در فايـل هيـدر تصاوير لندست انجام شد. يس از آن تصحيحات تويـوخر افى و اتمسفرى بـا روش فلـش در محسيط ENVI صـورت كرفـت و

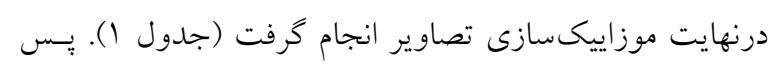




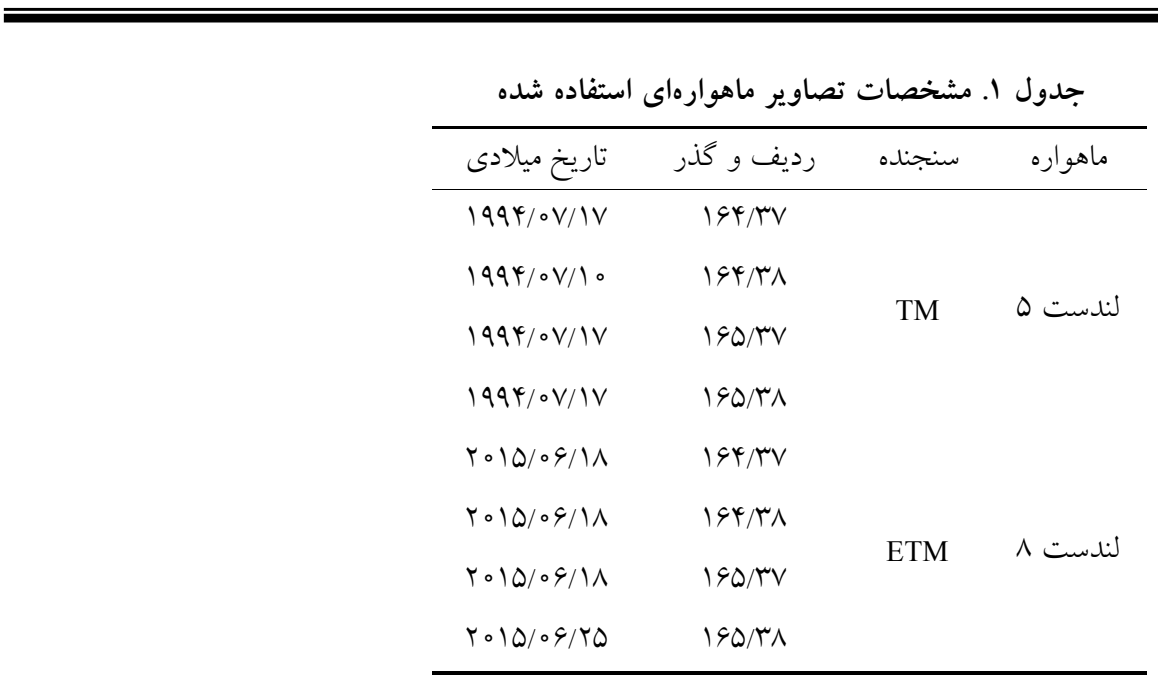

جدول r. طبقات يوشش اراضى تعريف شده و توصيف آنها براى منطقه مطالعاتى

\begin{tabular}{|c|c|}
\hline توصيف & 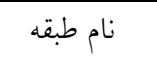 \\
\hline آيش و زير كشت & 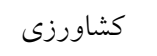 \\
\hline شهر، روستا،صنعت و جاده & انسانساخت \\
\hline مراتع درجه ا و r و r و درختان بر اكنده & 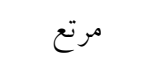 \\
\hline كليه جنگل هاى منطقه & 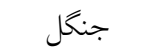 \\
\hline سد، تالاب و رودخانه & 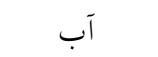 \\
\hline خاك لخت و صخره ها & بدون يوشش \\
\hline
\end{tabular}

حاصل از آن، حلدود آستانه جـــا كنــــه شـاخص آب تعيسين و

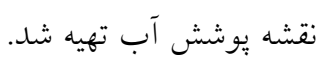

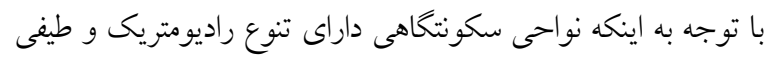

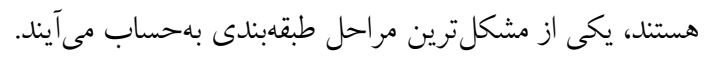

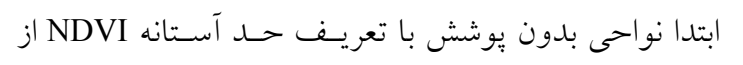

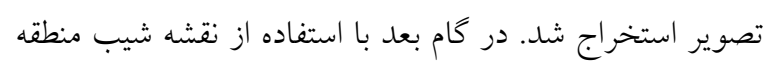

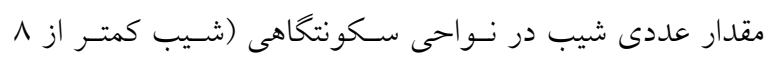

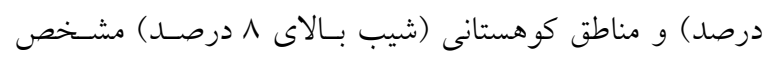

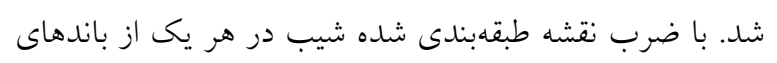

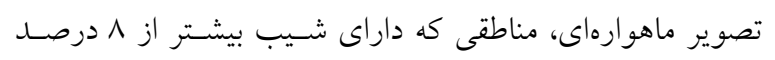

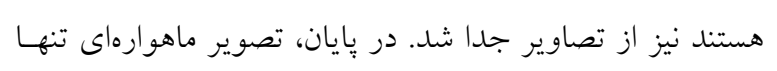

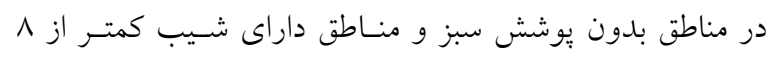

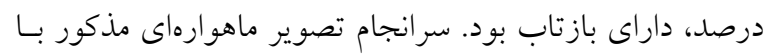

شـاخص وضـعيت يوشـش كيـاهى NDVI إز (Difference Vegetation Index

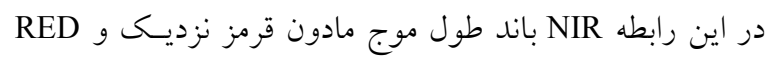
$\mathrm{NDVI}=\frac{(\mathrm{NIR}-\mathrm{RED})}{(\mathrm{NIR}+\mathrm{RED})}$

جهت تفكيك يوشش آب از شاخص تفاضـل نرمـال شـده آب NDWI

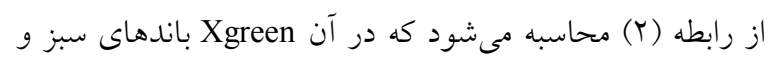
Xnir NDWI $=\frac{\left(x_{\text {green }}-x_{\text {nir }}\right)}{\left(x_{\text {green }}+x_{\text {nir }}\right)}$ با تهيه نقشه شاخص تفاضل نرمـال شـده آب و تفسـير اعـداد 


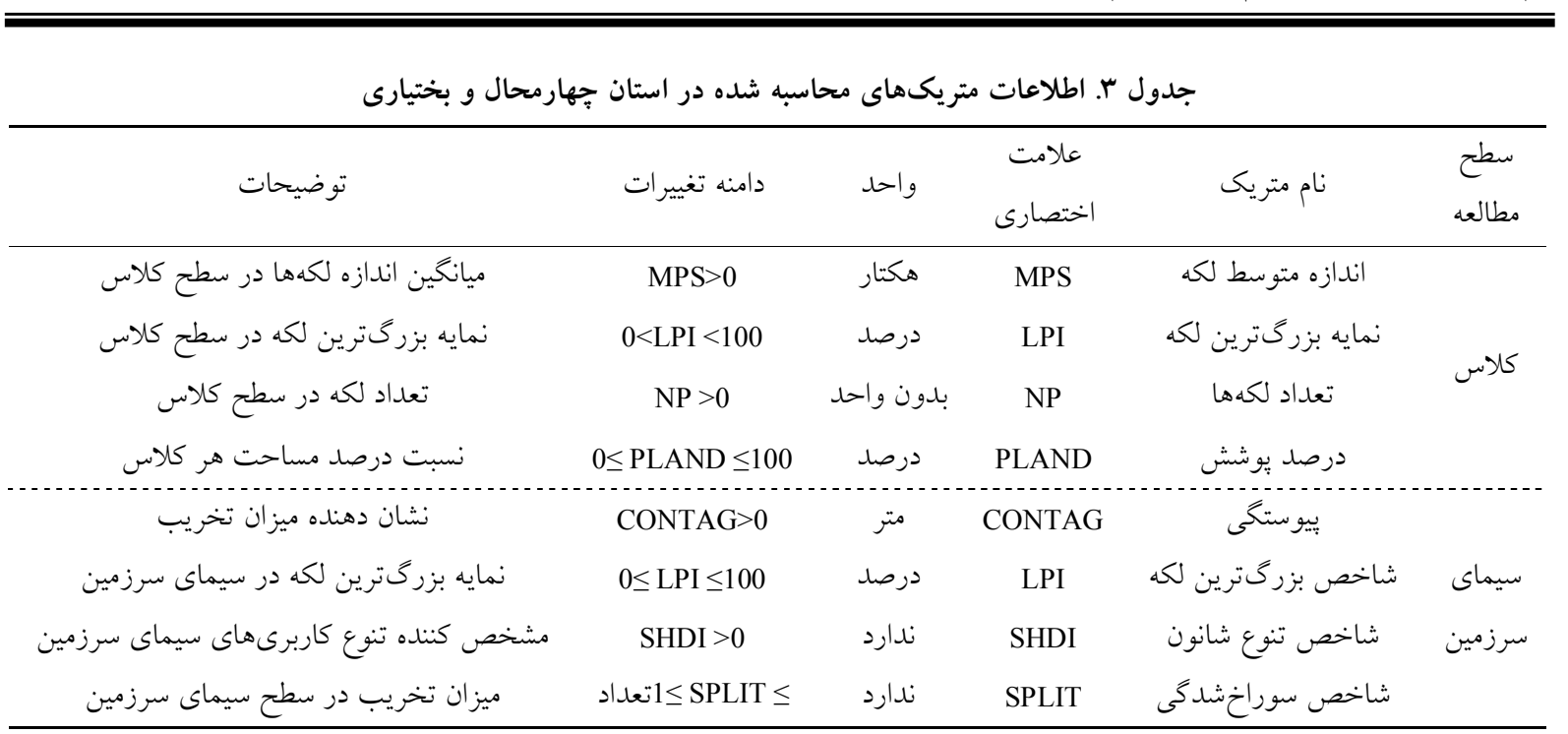

متوسط لكه (MPS)، نمايه بزرگترين لكه (LPI)، تعـداد لكـه و درصــ يوشسش (PLAND) انتخـاب شـد. در سـطح (P) سيماى سرزمين نيز از جهار متريـك بيوسـتكى (CONTAG)، شاخص تنوع شانون (SHDI)، شاخص بزرگترين لكه (LPI) و شاخص سوراخشدى (SPLIT) استفاده شد (جدول س).

\section{نتايج}

براى تصوير طبقهبندى شده سال هاه r، صحت كلسى كـه بـا

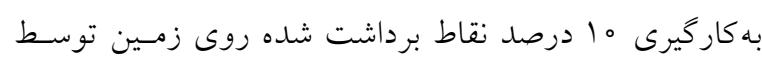
GPS سال 1994 صحت كلى، كه با كنترل نقشههـاى تويـو گرافى و عكسهاى هوايى موجود كنترل شد، رب/ 9 د درصد بـه دسـت

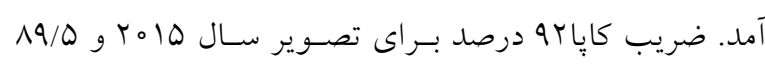
درصد براى سال 1994 بهدست آمـد. همـانطـور كـه نقشـه كاربرى اراضى سرزمين در دو مقطع زمانى نشان مسىدهــ از

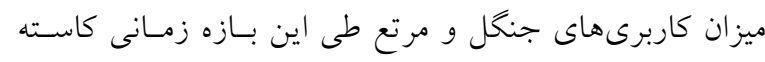
شده و از سوى ديخر ميزان كاربرى بدون بوشش افزايش يافته

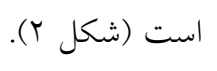

بررسى تغييرات طـى سـال هـاى r 1994 الـى هاه ب نشـان

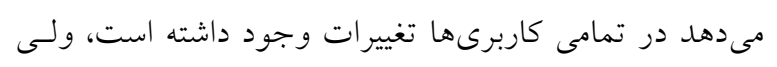
ميزان تغييرات رخ داده در كاربرىهاى منطقه مطالعاتى با نرخ
اسـتفاده از روش طبقـهبنـدى حسـداكثر احتمــال بـه دو طبقـه

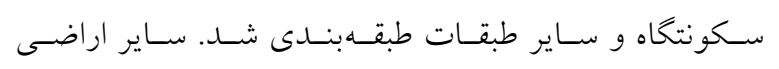
باقى مانده بهعنوان اراضى باير گروهبندى شد. درنهايت كليه نقشههاى توليد شده در نرمافزار

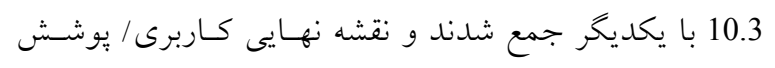
زمين بهدست آمد. جهت تعيين ميزان صحت طبقهبندى نقشـه يوشش اراضسى سـال هاه ب، مشـاهدات ميــانى و كنتـرل در Google Earth 1994، نقشههاى تويو گرافى، عكسهاى هوايى موجود، تفسير براي بصرى و تصاوير رنخى كاذب استفاده شد. براى آشكارسازى تغييرات كـاربرىهـا در اسـتان در بـازه زمانى مورد مطالعه، با استفاده از روش CROSS TAB مقايسه يس از طبقهبندى استفاده شد كه با مقايسـه دو نقشـه مسـتقل طبقهبندى شده كاربرى/ بوشـش زمسين در دو زمـان متفـاوت

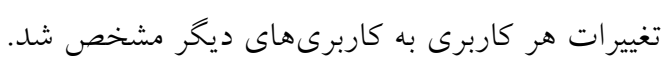
با توجه به اينكه روش مقايسه يس از طبقهبندى، اطلاعات

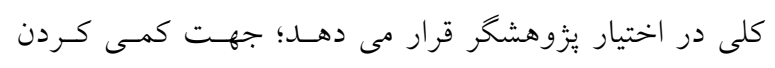
تغييرات رخ داده در كليه كاربرىها با استفاده از متريـكهــاى

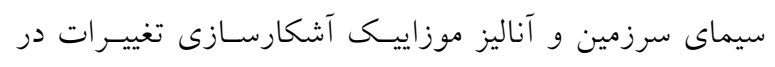

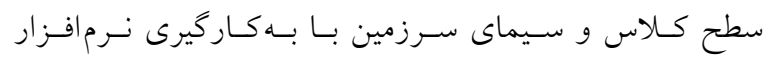
Fragstat4.1 انجام شد. در سطح كلاس، جهار متريكى انـدازه 

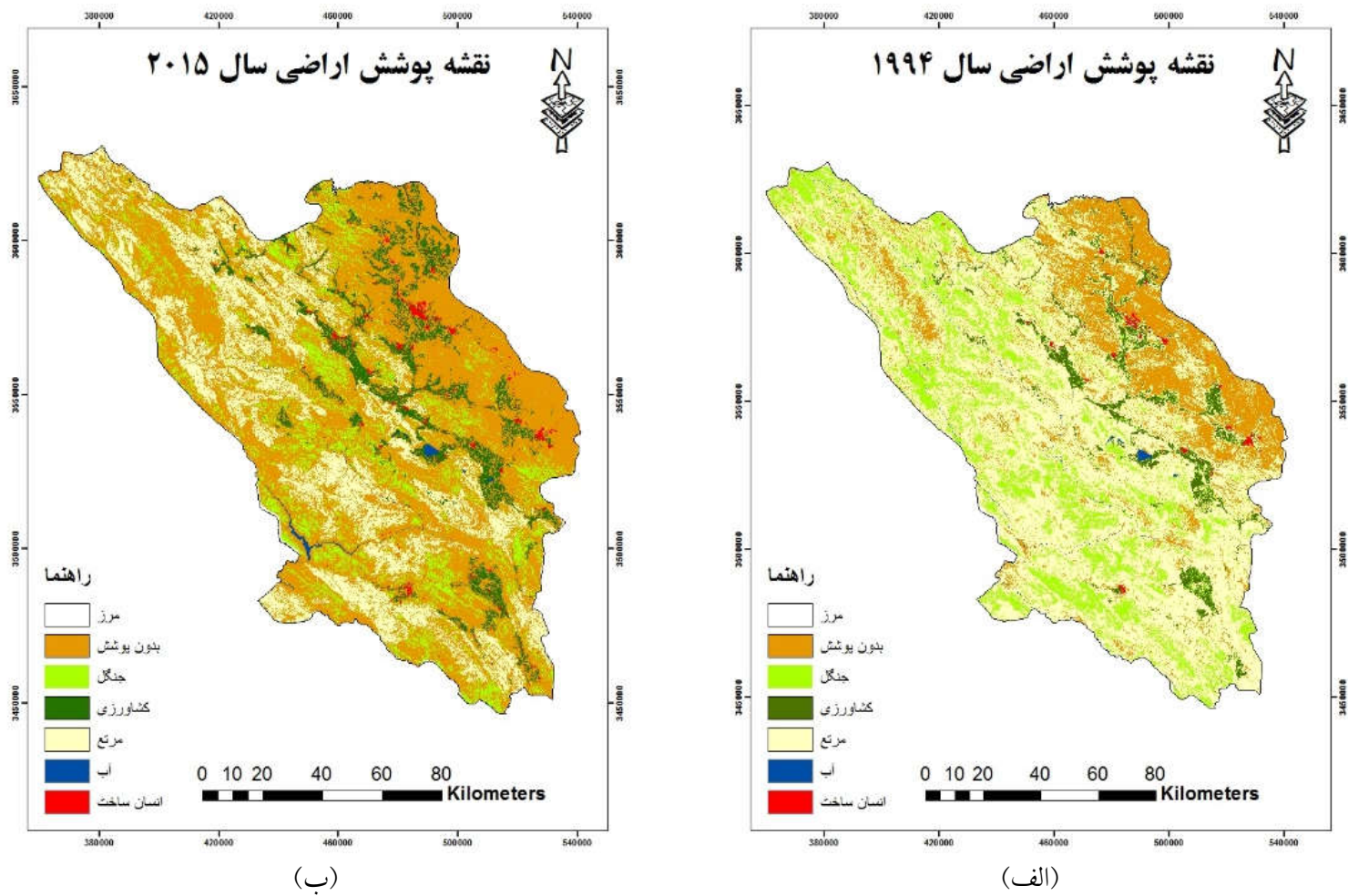

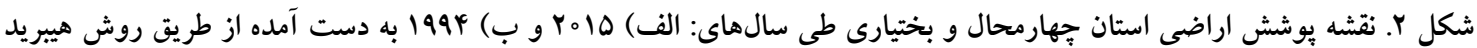

سطح كلاس براى دو سال 1994 و 010 در جدول ه نمـايش داده شده است.

همجنــين بـا توجسه بـه تغييـرات رخ داده در كـاربرىهـاى كوناگون استان دو شاخص نرخ تخريسب انسـانى (رابطـه ؟) و نرخ تخريب هر كاربرى رابطه (Y) محاسبه شد (IV). $\mathrm{HIR}=\frac{\mathrm{PPA}-\mathrm{PA}+\mathrm{PRP}}{\mathrm{A}}$

كه در آن HIR نرخ تخريسب كـاريرىهـا توسط انسـان، PPA مساحت كاربرى مورد نظر در زمـان اوليسه دوره، PA مسـاحت كاربرى مورد نظر در زمان كنونى دوره، PRP كاربرى مصنوعى كه در زمان كنونى دوره به منطقه اضـافه شــه اسـت و A كـل

$\mathrm{XDR}=\frac{\mathrm{PPA}-\mathrm{PA}}{\mathrm{PPA}}$

كه در آن XDR نرخ تخريب كاربرى مورد نظر، PPA مسـاحت كاربرى مورد نظر در زمان اوليه دوره و PA مسـاحت كـاربرى
و اندازههاى مختلف رخ داده است. بيشترين تغييرات طى ايسن بازه زمانى مربوط به تبديل مراتع با ارزش استان به زمسينهـاى باير است. همجنين بررسى تغييرات نشـان مسىدهــ كـه سـطح جنگل هاى استان نيز با كاهش، سطح زمسينهـاى كشـاورزى و مناطق انسانساخت با افزايش روبهرو بوده است (جدول \&). براى بهدست آوردن تصويرى كلى از منطقه مورد مطالعه از آناليز Percentage of Landscape) PLAND)در سـطح كـلاس استفاده شد. نتايج حاصل از آناليز PLAND نشان داد كه در بازه زمانى مورد مطالعه اراضى بـاير r ب/هץ درصــ افـزايش سـطح

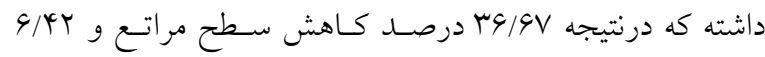
درصد كاهش سطح جنخـل هـا بـوده اسـت. مسـاحت اراضسى كشاورزى r/r درصد و اراضى انسان ساخت و يوشش آب نيز با اندكى تغيير افزايش سطح داشتهانــ كـه تغييـرات سـطح آب بهدليل احداث سد در منطقه بوده است. نتايج آناليز متريكهاى MPS، LPI، 


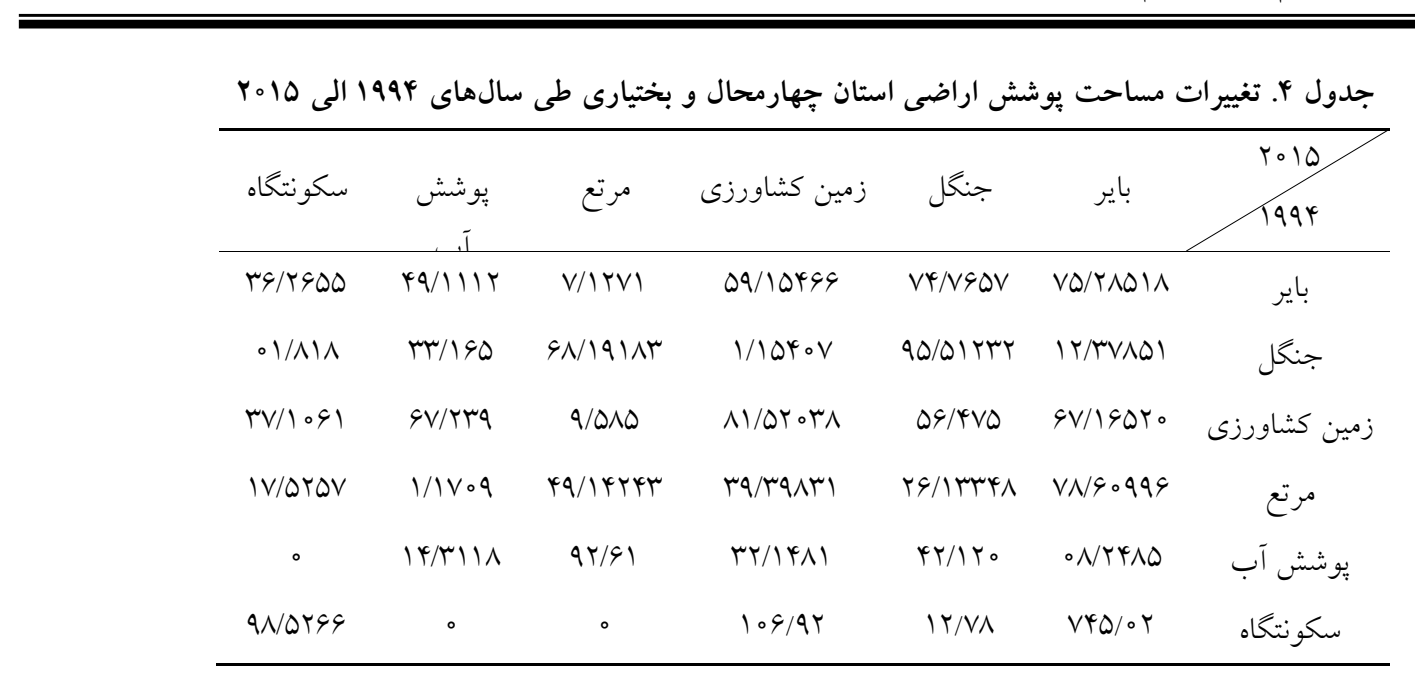

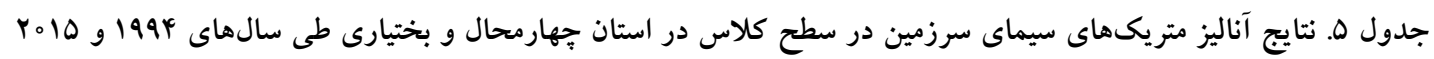

\begin{tabular}{|c|c|c|c|c|c|c|c|c|}
\hline \multicolumn{2}{|c|}{ متريك LPI } & \multicolumn{2}{|c|}{ متريك MPS(ha) } & \multicolumn{2}{|c|}{ متريك NP } & \multicolumn{2}{|c|}{ متريك PLAND } & \multirow{2}{*}{ نام كاربرى } \\
\hline سال 10 ro & سال 1994 & سال Q10 r & سال 1994 & سال rold & سال 1994 & سال 10 ro & سال 1994 & \\
\hline FG/TKYA & $4 / 19 V V$ & $9 / 9990$ & $9 / 49 Y 0$ & $9090 \mathrm{~V}$ & YAYA & $\Delta N / D \wedge r Y$ & $19 / T \& V 4$ & باير \\
\hline$\circ / M V \circ r$ & $\circ / V I T \circ$ & r/l099 & $r / 999$. & NGYAY & VereV & $11 / 1991$ & $|N / T A| \mid$ & جنگل \\
\hline $1 / 0901$ & ०/rova & N/OVN & $9 / 7901$ & lerke & VGro & V/OGY。 & $\varphi / r 401$ & زمين كشاورزى \\
\hline T/NTAS & rQ/qRYO & MYJVYYA & $1 r / 9 \circ \Delta T$ & १९Vद & VTaqr & ro/9VIV & $\Delta V / T Y M$ & مرتع \\
\hline$\circ / r \circ \Delta \Lambda$ & $0 / Y_{0} \circ 1$ & TYY/OYNI & rYQ/VYOO & r4 & 11 & $0 / \pi q 01$ & $0 / 444 a$ & يوشش آب \\
\hline $0 / 4 V 11$ &.$/ 09 \mathrm{VV}$ & $11 / 9110$ & TH/TYYO & IrqV & TGY & -/9TQQ & $\circ / \Gamma V \nabla$ & سكونتخاه \\
\hline
\end{tabular}

جدول و. نتايج آناليز دو شاخص نرخ تخريب انسانى و نرخ تخريب كاربرىهاى گوناكون در استان جهارمحال و بختيارى

\begin{tabular}{|c|c|c|c|c|}
\hline نرخ تخريب كاربرى & نرخ تخريب انسانى (درصد) & مساحت (هكتار) ro10 & مساحت (هكتار) 1994 & نوع كاربرى \\
\hline$-Y_{0} \circ$ & $-r q$ & $991 \pi \Delta 9 / \pi$ & MIS०Vo & باير \\
\hline +ro & $+9 / 4$ & $194944 / 49$ & Т৭৭৭৭४/०ᄉ & جنكل \\
\hline$-V_{0}$ & $-r$ & $\mid K Y \circ G V / 19$ & $V|00| / 9$ & زمين كشاورزى \\
\hline$+9 r$ & $+r_{4}$ & MTarlo/rv & 941009 & مرتع \\
\hline$-\wedge$ & $-0 / 0$ r & $94 \circ 1 / 94$ & $\Delta 9 \circ V / 99$ & يوشش آب \\
\hline-140 & $-0 / 0$ & $10194 / 94$ & $9 \mid \wedge 9 / 9$ & سكونتخاه \\
\hline
\end{tabular}

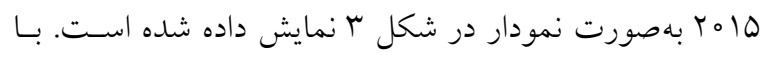

مورد نظر درزمان كنونى دوره است (جدول 9).

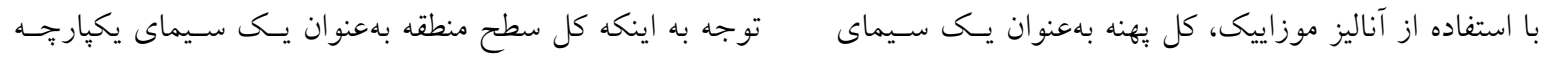

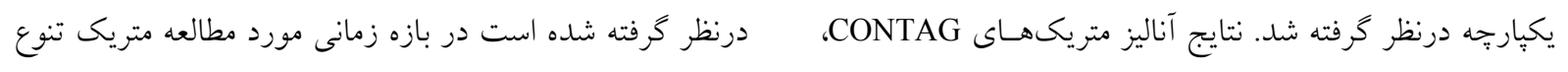

SPILIT SHDI، SPI 


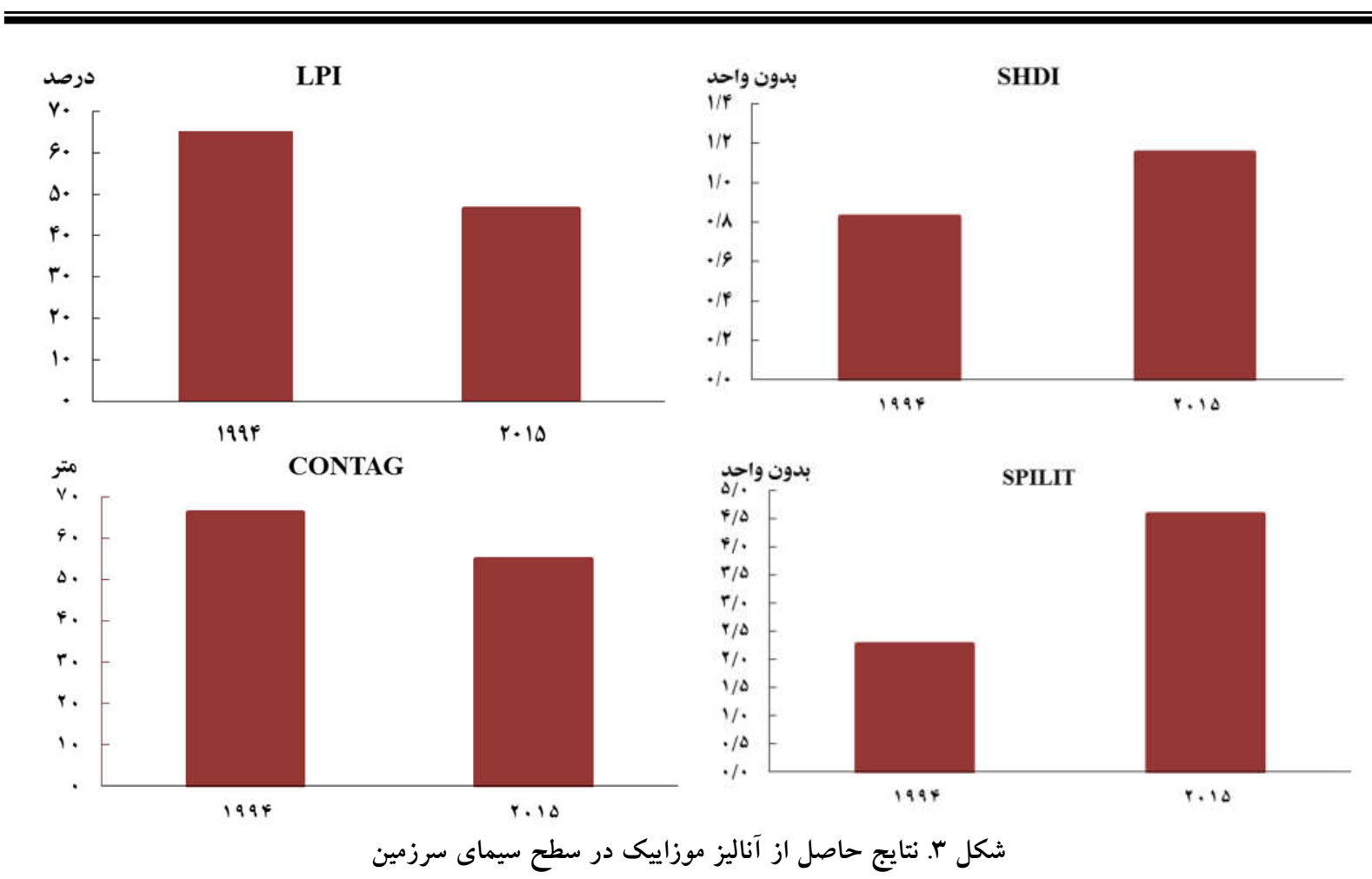

مساحت و كاهش تعداد لكه مناطق باير نيز از عواقـب تخريـبـ مراتع است. لكه هاى انسانساخت در بازه زمـانى مطالعـه شــه

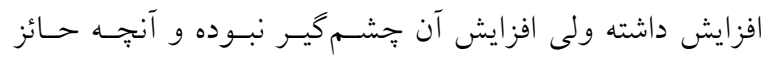
اهميت است و باعث تكهتكه شدن كاربرىها شده قرار حـرفتن منطقه براى ييلاق است كه تخريب در منطقه را به دنبال داشـته

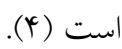

سطح بوشش جنگلى استان جهارمحسال و بختيـارى نيـز در بخش هايى كه در شيب و ارتفاع بـالا قـرار كرفتـهانــ بـهدليـل صعبالعبور بودن و دور از دسترس بودن كمتر مـورد تخريسب قرار كرفته است. يوشش جنشلى مناطقى كـهـ در ارتفـاع بـايين

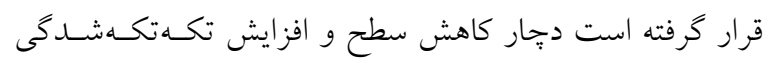
قرار گرفته كه اين امـر بـهدليـل دخالـت و حضـور انسـانى در تخريب جنگل ها است. با توجه به اينكسه يكسى از نقـاط قـوت

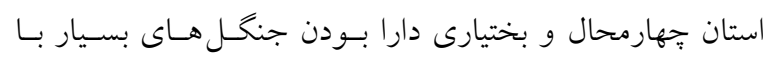
ارزش است عدم كنترل تخريب جنغل ها مىتواند تنوع زيسـتى را به ورطه نابودى بكشاند. افزايش مساحت و تعداد لكههاى كشاورزى بهدليل تمركز و

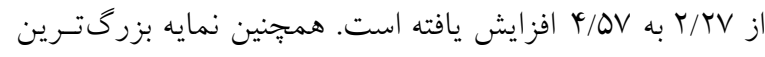

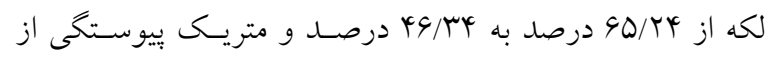
99/19 متر بـ 0Y/199 متر كاهش داشته است.

\section{بحث و نتيجه گيرى}

با توجه به اينكه كمّى كردن الخوهـاى سـيماى سـرزمين امـرى

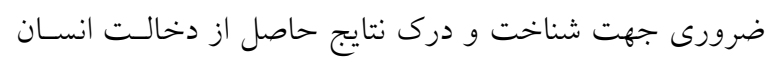
در طبيعت است؛ لذا درى تغييرات مكانى و زمانى كاربرىهـاى كوناكون در قالب متريكها مىتوانـد كمــى قابـل تـو جهى بـــ

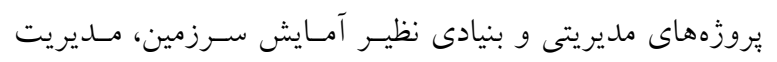
منابع و حفاظت تنوع سيماى سرزمين كند (19). خلاصه نتايج اين تحقيق نشان داد افـزايش ميـانكين انــازه لكه و كاهش قابل ملاحظه تعداد لكه در مراتع اسـتان بـهدليـل كاهش قابل توجه مساحت بوده كه بـهنظر مسىرسـد ناشسى از تبديل و تخريب كاربرىها و جراى بى اندازه دام در منطقه است كه خود عواقب جبراننايذيرى از جمله فرسايش خاك و كاهش

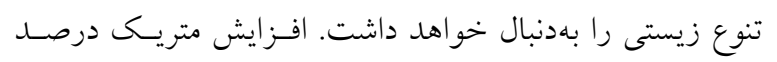




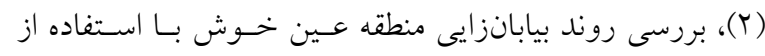

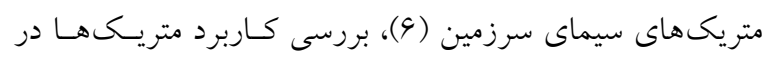

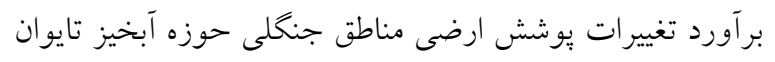

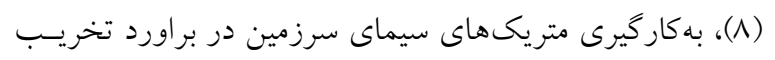

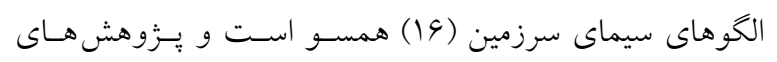

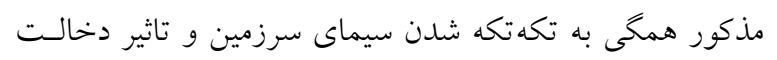
انسان و توسعه لكههاى مصنوعى اشاره كردهاند.

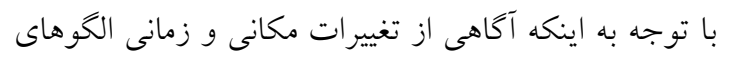

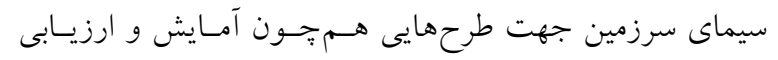

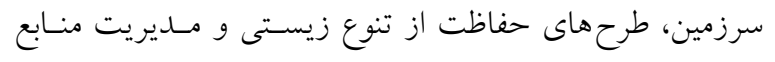

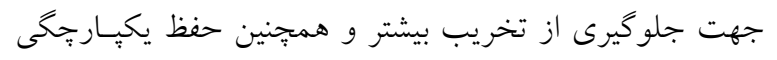

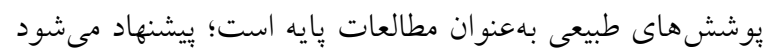

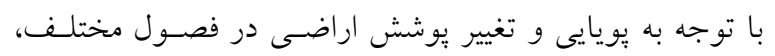

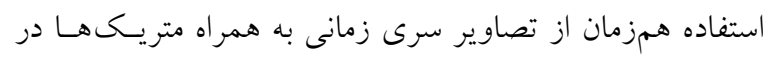

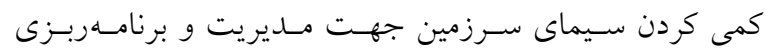
طرحهاى كلان استفاده شود.
افزايش حجـم آب در منطقـهـ اسـت كـهـ باعـث رشـــ و رونسق

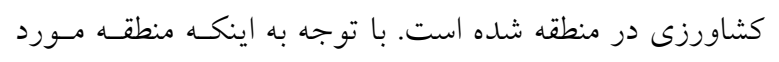

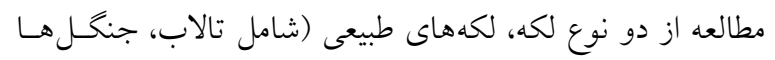

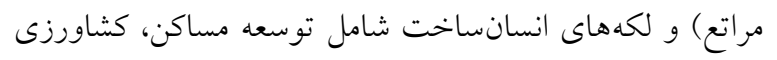

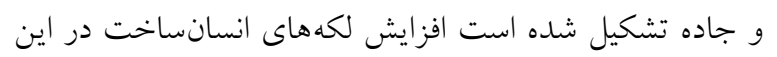
يزووهش با كاهش بيوستخى و نقوذ بين لكههاى طبيعى بهعنسوان نمايهاى از تخريب سيماى سرزمين قلمداد مى شود.

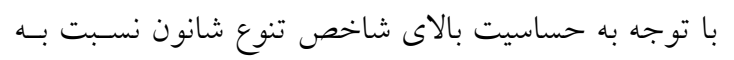

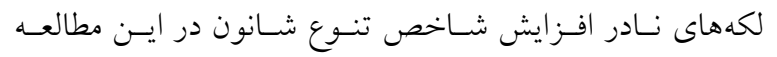

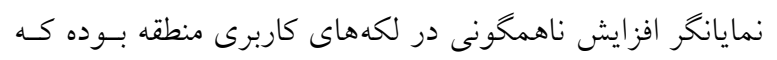

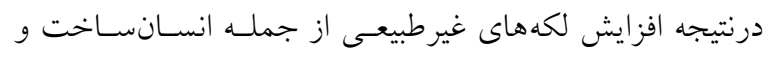

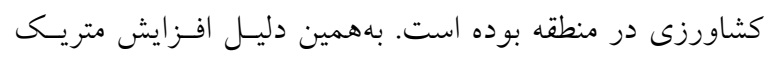

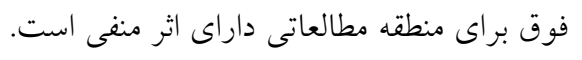

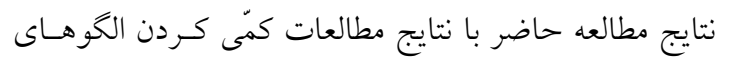
سيماى سـرزمين در منطقـه مركـزى اصفهان، يــايش تغييـرات

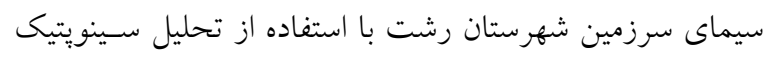

منابع مورد استفاده

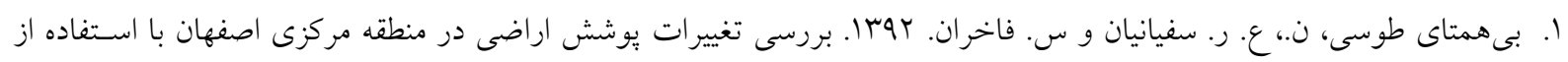

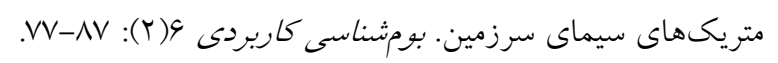

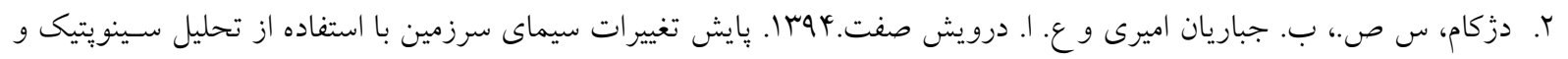

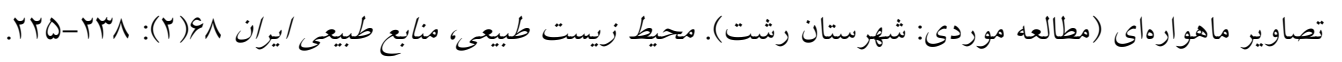

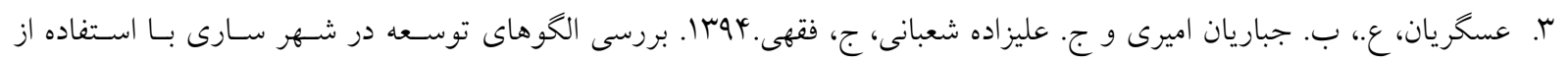

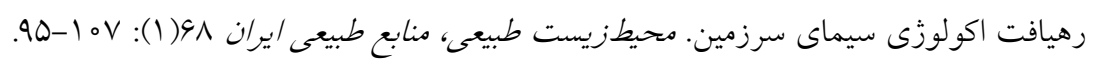

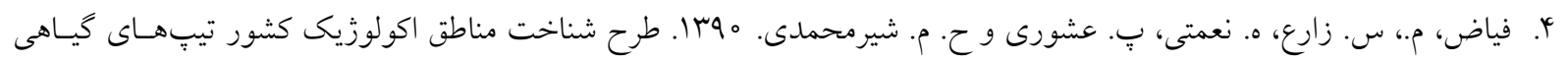

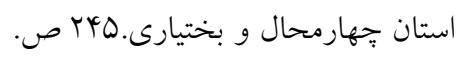

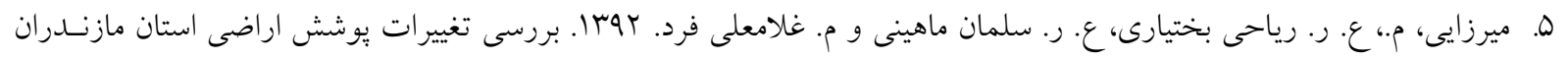

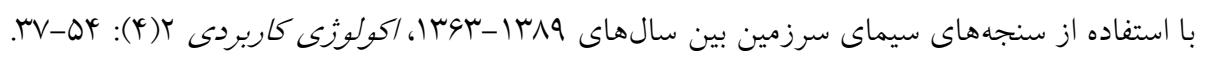

6. Arekhi, S. and B. Komaki. 2015. Detection and assessing desertification using landscape metrics in GIS environment (case study: Ain-e- khosh region, Iran). Environmental Resources Research 3(2): 121-137.

7. Buyantuyev, A., J. Wu and C. Gries. 2009. Multiscale analysis of the urbanization pattern of the Phoenix metropolitan landscape of USA: Time, space and thematic resolution. Landscape and Urban Planning 94: 206-217.

8. Chun-Kuo, Y., and L. Shyue-Cherng. 2015. Application of landscape metrics and a Markov chain model to assess land cover changes within a forested watershed, Taiwan. Hydrological Processes 29: 5031-5043. 
9. Deng, J. S., K. Wang, Y. Hong and J. G. Qi. 2009. Spatio- temporal dynamics and evolution of land use change and landscape pattern in response to rapid urbanization. Landscape and Urban Planning 92(3-4): 187-198.

10. Herold, M., H. Couclelis and K. C. Clarke. 2005. The role of spatial metrics in the analysis and modeling of urban land use change. Journal of Computers, Environment and Urban Systems 29: 369-399.

11. Lausch, A. and F. Herzog. 2002. Applicability of landscape metric for the monitoring of land scape change: Issues of scale, resolusion and interpretability. Journal of Ecological Indicators 2(1-2): 3-15.

12. McGarigal, K. and B. J. Marks. 1995. Spatial pattern analysis program for quantifying landscape structure. Gen. Tech. Rep. PNW-GTR- 351. US Department of Agriculture, Forest Service, Pacific Northwest Research Station.

13. Opeyemi, Z. A. 2006. Change detection in land use and land cover using remote sensing data and GIS, MSc thesis, Department of Geography, University of Ibadan.

14. Schindler, S., K. Poirazidis and T. Wrbka. 2008. Towards a core set of landscape metrics for biodiversity assessments: A case study from Dadia National Park, Greece. Ecological Indicators 8(5): 502-514.

15. Shao, G. and J. Wu. 2008. On the accuracy of land scape pattern analysis using remote sensing data. Landscape Ecology 23(5): 505-511.

16. Sherestha, M., A. York, C. Boone and S. Zhang. 2012. Land fragmentation due to rapid urbanization in the Phoenix Metropolitan Area: Analyzing the spatio-temporal patterns and drivers. Applied Geography 32: 522-531.

17. Tengteng, S., L. Wenpeng, C. Guangsheng, G. Pupu and Z. Ying. 2016. Wetland ecosystem health assessment through integrating remote sensing and inventory data with an assessment model for the Hangzhou Bay, China. Science of The Total Environment 566-567:627-640. doi: 10.1016/j.scitotenv.2016.05.028.

18. Turner, M. G., R. H. Gardner and R. V. ONeill. 1994. Quantitative Methods in Land Scape Ecology: The Analysis and Interpretation of Land Scape Ecology . Springer Verlage pub., USA.

19. Uuemaa, E., U. Mander and R. Marja. 2013. Trends in the use of landscape spatial metrics as landscape indicators: A Review. Ecological Indicators 28: 100-106.

20. Veldkamp, A. and E. F. Lambin. 2001. Predicting land use change. Agriculture, Ecosystem, Environment 85:1-6. 


\title{
Land Cover Change Detection of Chahar Mahal Bakhtiari Province using Landscape Metrics (1994-2015)
}

\author{
R. Daneshmandparsa ${ }^{1,2^{*}}$, R. Mirzaei ${ }^{2}$ and N. Bihamtaitoosi ${ }^{1}$
}

(Received: Dec. 03-2016; Accepted: Oct. 23-2018)

\begin{abstract}
Due to the importance of accessibility to updated and timely information regarding land cover changes, it is necessary for researchers and managers to assess such provincial level changes to help the planning process and prevent the damages caused in various regions. To this end, the Chaharmahal and Bakhtiari Province land cover changes from 2015-1994 were developed in six main classes using the hybrid method. Then land cover changes were determined by applying "after-classification comparison" and "landscape metric". Therefore, MPS, LPI, NP and PLAND metrics were calculated at the class level, and SHDI, LPI, CONTAG SPILIT INDEX metrics were calculated to quantify the landscape patterns at the landscape level. Finally, for each land use type, the destruction rates and the human destruction index were calculated separately. The results indicated a sharp decline of $\% 36.67$ in pastures and $6.42 \%$ in the forests areas, as well as an increase $39.32 \%$ in the barren lands. In such a manner, the landscape is more fragmented, disordered (or unsystematic) and discontinuous plus it has become more diverse for the studied time period coverage. So, if the current trend continues, the a sharp decrease in the ecosystem services and functions is likely to occur.
\end{abstract}

Keywords: Chahar Mahal and Bakhtiari province, landscape patterns, remote sensing, metrics, hybrid.

1. Dept. of Natur. Resour., Isf. Univ. of Technol., Isfahan, Iran.

2. Dept. of the Environ., Faculty of Natur. Resour. and Earth Sci, Univ. of Kashan, Kashan, Iran.

*: Corresponding Author, Email: r.daneshmandparsa@of.iut.ac.ir 